\title{
Nickel (Ni) Effects on Shoots and Roots Dry Matter and on Ni Concentration in Shoots of Mojito (Mentha $x$ villosa) and Lavender (Lavandula angustifolia)
}

\author{
Pantelis E. BAROUCHAS ${ }^{1}$, Anastasia AKOUMIANAKI-IOANNIDOU ${ }^{2}$, Aglaia LIOPA-TSAKALIDI ${ }^{1}$, Alexandra \\ SALTA $^{2}$, Nicholas K. MOUSTAKAS ${ }^{3^{*}}$ \\ ${ }^{1}$ Technological Educational Institute of Western Greece, Greece \\ ${ }^{2}$ Laboratory of Floriculture and Landscape Architecture, Department of Crop Science, School of \\ Agriculture, Engineering and Environmental Sciences, Agricultural University of Athens, 75 Iera Odos, \\ 118 55, Athens, Greece. \\ ${ }^{3}$ Laboratory of Soil Science and Agricultural Chemistry, Department of Crop Science, School of \\ Agriculture, Engineering and Environmental Sciences, Agricultural University of Athens, 75 Iera Odos, \\ 118 55, Athens, Greece. \\ *corresponding author: nmoustakas@aua.gr
}

BulletinUASVM Horticulture 76(1) / 2019

Print ISSN 1843-5254, Electronic ISSN 1843-5394

DOI:10.15835/buasvmcn-hort: 2018.0031

\begin{abstract}
Nickel is an essential trace element for plants, but excessive Ni levels in the soil can result in toxicity to plants. The aim of this research was to examine the effect of Ni on shoots dry matter (SDM), roots dry matter (RDM) and on Ni concentrations in SDM (Ni-SDM) of mojito and lavender plants. A completely randomized block design with five treatments $\left(0,5,10,20\right.$ and $\left.40 \mathrm{mg} \mathrm{Ni} \mathrm{L}^{-1}\right)$ and five replications for each treatment and plant species was conducted in pot experiments. Nickel was applied to the pot medium as $\mathrm{NiCl}_{2} 6 \mathrm{H}_{2} \mathrm{O}$. No visible toxic or inhibitory symptoms were observed on the plants due to the increasing rates of Ni applications. The SDM and RDM were not affected by $\mathrm{Ni}$ in the studied plants. Ni-SDM of mojito and lavender raised with increasing rates of Ni above 20 and $10 \mathrm{mg} \mathrm{Ni} \mathrm{L}^{-1}$, respectively.
\end{abstract}

Keywords: heavy metals, culinary herb, medicinal herb

\section{Introduction}

Nickel (Ni) occurs abundantly in igneous rocks as a free metal or as a complex along with iron. It stands at twenty-second position amongst the most abundant elements in the Earth crust (Sunderman and Oskarsson, 1991). Additionally, anthropogenic activities release $\mathrm{Ni}$ into the soil through various sources such as smelting, burning of fossil fuel, vehicle emissions, disposal of house hold waste, municipal and industrial wastes, metal mining, fertilizer application, and organic manures (Alloway 1995). During the last decades, Ni has become a serious concern as its concentration has reached up to $26,000 \mathrm{mg} \mathrm{kg}^{-1}$ in polluted soils (Alloway 1995; McGrath 1995) and $0.2 \mathrm{mg} \mathrm{L}^{-1}$ in polluted surface waters (Zwolsman and Van Bokhoven, 2007). Nickel is an essential trace element for plants, but excessive Ni levels in the soil can result in toxicity to plants. The common indicators of $\mathrm{Ni}$ phytotoxicity include inhibition of germination, leaf spotting, chlorosis, abnormal flower shape, reduced growth of roots and shoots, deformation of plant parts, poor branching, and decreased yield. The toxicity of $\mathrm{Ni}$ in plants has become a world-wide problem threatening sustainable agriculture as well. The 
critical toxicity level of $\mathrm{Ni}$ is more than $10 \mathrm{mg} \mathrm{kg}^{-1}$ DW in sensitive species (Kozlow, 2005), $50 \mathrm{mg} \mathrm{kg}^{-1}$ DW in moderately tolerant species and 1,000 mg $\mathrm{kg}^{-1} \mathrm{DM}$ in Ni hyper accumulator plants such as Alyssum and Thalspi species (Kupper et al., 2001; Pollard et al., 2002). The impact of Ni toxicity on the physiology of plants depends on the type of plant species, growth stage, cultivation conditions, $\mathrm{Ni}$ concentration and exposure time (Kabata-Pendias and Pendias, 2001) in the soil. More information on $\mathrm{Ni}$ levels in plant tissues that are consumed by mammals, and their effect on plant growth, is required. Several medicinal and culinary plants manifest a tendency to take up high amounts of heavy metals therefore we studied Mentha $\times$ villosa (Lamiaceae) which is an aromatic and medicinal plant rich in essential oils (Alaize de Martins et al., 2007) and Lavandula angustifolia (Lamiaceae) a native Mediterranean small shrub with aromatic leaves, flowers attractive characteristics and also rich in essential oils (Lauren et al., 2016). Both spices are used in cosmetics, hygiene products, and traditional medicines. Mojito (Mentha $x$ villosa) and lavender (Lavandula angustifolia) are medicinal and culinary herbs and up till now we have little information regarding their response to increasing concentration of $\mathrm{Ni}$ in the soil. Consequently the objectives of this research were to examine the effect of $\mathrm{Ni}$ on dry matter (DM) and $\mathrm{Ni}$ concentrations in the shoots of mojito and lavender.

\section{Materials and methods}

Pot experiments in a completely randomized blockdesign with five treatments $(0,5,10,20$ and 40 $\mathrm{mg} \mathrm{Ni} \mathrm{^{-1 }}$ ) and five replications for each treatment and plant species (50 pots totally for each plant) were conducted under greenhouse conditions at the Technological Education Institute of Western Greece in order to study the effects of $\mathrm{Ni}$ on shoots (leaves+stems) and roots dry matter, and on the concentration of $\mathrm{Ni}$ in shoots of Mojito (Mentha $\times$ villosa) and lavender (Lavandula angustifolia). The duration of the experiments was four months. For the experiments, seeds of mojito were sown in palettes of 20 compartments. After four weeks the plants were transplanted to the experimental pots (made of black plastic, $14 \mathrm{~cm}$ in diameter and $0.5 \mathrm{~L}$ volume) filled with a substrate of peat-perlite $1: 1$ $(\mathrm{v} / \mathrm{v})$ with $\mathrm{pH}=5.6$, organic matter content $90 \%$ $95 \%$ and Electrical Conductivity $0.3 \mathrm{~S} \mathrm{~m}^{-1}$. Nickel was applied as $\mathrm{NiCl}_{2} 6 \mathrm{H}_{2} \mathrm{O}$ twice a week with $25 \mathrm{ml}$ of each treatment per pot for five weeks (total $250 \mathrm{ml}$ per pot of each treatment for the whole cultivation period, i.e. $25.3 \mathrm{mg} \mathrm{Ni}, 50.6 \mathrm{mg} \mathrm{Ni}, 101.2 \mathrm{mg} \mathrm{Ni}$ and $202.5 \mathrm{mg} \mathrm{Ni}$ for $5 \mathrm{mg} \mathrm{Ni} \mathrm{L}{ }^{-1}, 10 \mathrm{mg} \mathrm{Ni} \mathrm{L}^{-1}, 20 \mathrm{mg}$ $\mathrm{Ni} \mathrm{L}^{-1}$ and $40 \mathrm{mg} \mathrm{Ni} \mathrm{L}^{-1}$, respectively). Fertilization was performed approximately every two weeks, using a commercial fertilizer (Nutrileaf-60) with $2 \mathrm{mg} \mathrm{N}, 2 \mathrm{mg} \mathrm{P}_{2} \mathrm{O}_{5}$, and $2 \mathrm{mg} \mathrm{K}_{2} \mathrm{O}$ for each pot (the content of $\mathrm{Ni}$ in the fertilizer was negligible). At the end of the experiment, leaves, stems and roots were harvested and oven-dried at $50{ }^{\circ} \mathrm{C}$ to constant weight, ground in a stainless steel Wiley mill and passed through a $250 \mu \mathrm{m}$ plastic sieve, 0.5 $\mathrm{g}$ of plant parts smaller than $250 \mu \mathrm{m}$ in diameter from each pot were placed in beakers and ashed at $450{ }^{\circ} \mathrm{C}$. The residue was dissolved in $5 \mathrm{ml}$ of $6 \mathrm{~N} \mathrm{HCl}$. The clear solutions were analyzed by ICPOES (Thermo Scientific iCAP 6000). ANOVAs were calculated using STATISTICA ${ }^{\mathrm{TM}}$ Ver. 8.0 (StatSoft 2008). Where a significant difference was found, the Duncan's Multiple Range Test at the 5\% level of probability was used to compare individual treatment means.

\section{Results and Discussion}

No visible toxic or inhibitory symptoms were observed on the plants due to the increasing rates of Ni treatments. Results indicated that SDM and RDM were not affected by $\mathrm{Ni}$ in the studied plants (Tab. 1 and 2). Ni-SDM of mojito and lavender raised with increasing rates of $\mathrm{Ni}$ above 20 and 10 mg Ni L ${ }^{-1}$, respectively (Tab. 1 and 2). Nickel uptake by shoots of mojito grown in an acid medium is approximately five times greater than the Ni uptake by mojito grown in a neutral medium (Tab. 1 and 2). These values of $\mathrm{Ni}$ are greater than the amounts of $\mathrm{Ni}$ added in the medium indicating that mojito is a nickel accumulator when grown in an acid medium, but more research is needed on this aspect.

\section{Conclusions}

No visible toxic or inhibitory symptoms were observed on the plants due to the increasing rates of $\mathrm{Ni}$ applied. Results indicated that the SDM and RDM were not affected by $\mathrm{Ni}$ in the studied plants. Ni-SDM of mojito and lavender raised with applying increasing rates of $\mathrm{Ni}$ above 20 and $10 \mathrm{mg} \mathrm{Ni} \mathrm{L}^{-1}$, respectively. Mojito is possibly a $\mathrm{Ni}$ accumulator when grown on acid substrate. 
Table 1. Shoots dry matter (M-SDM), roots dry matter (M-RDM), Ni concentration in shoots and Ni uptake by shoots in mojito as affected by Ni.

\begin{tabular}{|c|c|c|c|c|}
\hline $\begin{array}{c}\text { Ni added } \\
\left(\mathrm{mg} \mathrm{Ni} \mathrm{L}^{-1}\right)\end{array}$ & $\begin{array}{c}\text { M-SDM } \\
\text { (g) }\end{array}$ & $\begin{array}{c}\text { M-RDM } \\
\text { (g) }\end{array}$ & $\begin{array}{c}\text { Ni in shoots of } \\
\text { mojito } \\
\left(\mu \mathrm{g} \mathrm{g}^{-1} \mathrm{DW}\right)\end{array}$ & $\begin{array}{c}\text { Ni uptake by } \\
\text { shoots in mojito } \\
\text { ( } \mu \text { g per pot DW) }\end{array}$ \\
\hline 0 & 24.51 & 38.69 & $6.81 \mathrm{~b}$ & 169.23 \\
\hline 5 & 24.89 & 35.42 & $8.83 \mathrm{ab}$ & 212.97 \\
\hline 10 & 23.81 & 38.64 & $8.92 \mathrm{ab}$ & 211.87 \\
\hline 20 & 21.09 & 43.26 & $11.08 \mathrm{a}$ & 236.09 \\
\hline 40 & 21.56 & 52.39 & $11.58 \mathrm{a}$ & 246.68 \\
\hline $\mathrm{F}$ & & & 5.53 & \\
\hline
\end{tabular}

Mean values/column followed by the same letter are not significantly different, according to Duncan's multiple range test, at $p \leq 0.05$; Mean values/column without letters indicate no significance by Duncan's test at $\mathrm{P} \leq 0.05$; DW=dry weight

Table 2. Shoots dry matter (L-SDM), roots dry matter (L-RDM), Ni concentration in shoots and Ni uptake by shoots in lavender as affected by $\mathrm{Ni}$.

\begin{tabular}{|c|c|c|c|c|}
\hline $\begin{array}{l}\text { Ni added } \\
\left.(\mathrm{mg} \mathrm{Ni} \mathrm{L})^{-1}\right)\end{array}$ & $\begin{array}{c}\text { L-SDM } \\
\text { (g) }\end{array}$ & $\begin{array}{c}\text { L-RDM } \\
\text { (g) }\end{array}$ & $\begin{array}{c}\text { Ni in shoots of } \\
\text { lavender } \\
\left(\mu \mathrm{g} \mathrm{g}^{-1} \mathrm{DW}\right)\end{array}$ & $\begin{array}{c}\text { Ni uptake by } \\
\text { shoots in lavender } \\
\text { ( } \mu \text { g per pot DW) }\end{array}$ \\
\hline 0 & 11.21 & 9.68 & $2.76 \mathrm{a}$ & $30.69 \mathrm{a}$ \\
\hline 5 & 10.82 & 9.28 & $2.96 \mathrm{a}$ & $33.31 \mathrm{a}$ \\
\hline 10 & 10.47 & 9.71 & $3.15 \mathrm{a}$ & $33.48 \mathrm{a}$ \\
\hline 20 & 9.38 & 11.48 & $3.92 \mathrm{a}$ & $35.87 \mathrm{a}$ \\
\hline 40 & 9.38 & 12.88 & $6.65 \mathrm{~b}$ & $60.23 \mathrm{~b}$ \\
\hline $\mathrm{F}$ & & & 6.42 & 4.10 \\
\hline
\end{tabular}

Mean values/column followed by the same letter are not significantly different, according to Duncan's multiple range test, at $p \leq 0.05$; Mean values/column without letters indicate no significance by Duncan's test at $\mathrm{P} \leq 0.05$; DW=dry weight.

\section{References}

1. Alloway BJ (1995). Heavy metal in soils. Blackie Academic and Professional, London, UK.

2. Kabata-Pendias A and Pendias H (2001). Trace elements in soils and plants, 3rd edn. CRC Press Inc, Boca Raton.

3. Kozlow MV, (2005) Pollution resistance of mountain birch, Betula pubescens subsp. czerepanovii, near the copper-nickel smelter: natural selection or phenotypic acclimation? Chemosphere 59:189-197.

4. Kupper H, Lombi E, Zhao FJ, Wieshammer G, McGrath SP (2001). Cellular compartmentation of nickel in the hyperaccumulators Alyssum lesbiacum, Alyssum bertolonii and Thlaspi goesingense. Journal Experimental Botany, 52:2291-3000.

5. Lauren AE, Soheil E, Mahmoud S (2016). Essential Oils in Food Preservation, Flavor and Safety . Chapter 57 . Lavender (Lavandula angustifolia) Oils. Academic press. Ed Victor R. Preedy. Department of Nutrition and Dietetics, King's College London.
6. Martins A, Craveiro A, Machado M, Raffin F, Moura T, Novák Cs, Éhen Zs, (2007). Preparation and characterization of Mentha $\times$ villosa Hudson oil- $\beta$-cyclodextrin complex. Journal of Thermal Analysis and Calorimetry, 88(2): 363371.

7. McGrath SP (1995). In: Alloway BJ (ed) Heavy metals in soils. Blackie Academic and Professional, London.

8. Pollard AJ, Powell KD, Harper HA, Smith JAC (2002). The genetic basis of metal hyperaccumulation in plants. Critical Review Plant Science, 21:539-566.

9. StatSoft Inc (1998) STATISTICA for Windows. Tulsa, OK; StatSoft Ic.

10. Sunderman FW, Oskarsson A (1991). Metals and their compounds in the environment. In: Merian E, Weinheim VCH (eds). pp. 1101-1126.

11. Zwolsman JJG, Van Bokhoven AJ (2007). Impact of summer droughts on water quality of the Rhine River-a preview of climate change. Water Science Technology 56:45-55. 